\title{
EFFECT OF COMBINED TREATMENT \\ WITH INSULIN AND OTHER HYPOGLYCEMIC DRUGS ON 5'AMP-ACTIVATED PROTEIN KINASE ACTIVITY IN LEUCOCYTES OF PATIENTS WITH DIABETES MELLITUS*
}

\author{
V. V. Pushkarev, L. K. Sokolova, V. M. Pushkarev, \\ Y. B. Belchina, T. S. Vatseba, M. D. Tronko \\ $S I$ «V. P. Komisarenko Institute of Endocrinology and Metabolism of NAMS of Ukraine», \\ Kiev, Ukraine \\ pushkarev.vm@gmail.com
}

AMPK (5’AMP-activated protein kinase) is a heterotrimer consisting of a catalytic subunit (a) and two regulatory subunits (B and Y). The $\mathrm{Y}$-subunit contains four potential sites that bind adenine nucleotides $[1,2]$. With energetic stress in the cell and an increase in the AMP concentration, ATP is replaced in the exchange centers by AMP, resulting in the allosteric activation of AMPK by phosphorylation of the 172 threonine of the a subunit by the LKB1 (liver kinase B1) complex in response to changes in cell energy, or CAMKKB (calcium-/ calmodulin-dependent kinase kinase B), which is activated by intracellular $\mathrm{Ca}^{2+}[3]$.

By direct phosphorylation of metabolic enzymes and transcription factors, AMPK stimulates catabolic processes - absorption of glucose, fatty acids and their conversion by mitochondrial oxidation and glycolysis. In addition, AMPK suppresses anabolic processes the synthesis of glucose, glycogen and lipids in the liver [4].

Metformin (1,1-dimethylbiguanide hydrochloride) is the main oral drug used in the clinic for the treatment of patients with type 2 diabetes (T2D). Metformin reduces hyperglycemia mainly by suppressing hepatic gluconeogenesis along with amelioration of insulin signal transduction. Nevertheless, the mechanism of its action remains insufficiently studied, especially regarding the participation of AMPK in the effects of metformin [5].

Type 2 diabetes mellitus is a progressive disease with a steady decrease in the func-

* The study was conducted in the Diabetology department of the SI «V. P. Komisarenko Institute of Endocrinology and Metabolism of NAMS of Ukraine», «To study the main ways of progression and mutual complication of vascular pathology in patients with type 1 diabetes mellitus with type 2 diabetes in order to improve modern methods of prevention and treatment» (State registration number: 0116U002163).

Institution, which financed the research: National Academy of Medical Sciences of Ukraine.

The authors assume responsibility for the published work.

The authors guarantee absence of competing interests and their own financial interest when carrying out the research and writing the article.

The manuscript was received by the editorial staff 28.11.2018. 
tion of pancreatic B-cells, which ultimately determines the inevitability of insulin therapy. Modern guidelines recommend early insulin therapy with the selection of an adequate and effective dose of insulin followed by timeous intensification. Early insulin therapy together with oral hypoglycemic agents is also offered in the updated ADA (American Diabetes Association) guidelines (2018) for managing patients with T2D [6]. At the same time, combined therapy of the first-line hypoglycemic drug metformin with insulin can lead to negative consequences and even increase the death rate of patients [7-9]. These facts require further study to understand the risks associated with the use of insulin and metformin in patients with diabetes.

The peripheral blood mononuclear cell include several types of cells that play a significant role in the development of pathological conditions of diabetes and its complications. Thus, the aim of our work was the study of the activity of the main energy sensor of cells AMPK in leucocytes from patients taking hypoglycemic drug both as monotherapy, and in combination.

\section{MATERIALS AND METHODS}

The study was conducted in the Diabetology department of the SI «V. P. Komisarenko Institute of Endocrinology and Metabolism of NAMS of Ukraine». 41 patients with type 1 diabetes (T1D) and T2D have been examined (26 female, 15 male, mean age $-50,1 \pm 4,8$ years, duration of DM 13,1 $\pm 4,9$ years). Mean HbA1c was $8,2+2,9 \%$, BMI $29,7 \pm 3,7 \mathrm{~kg} / \mathrm{m}^{2}$ without any differences for the groups- All patients signed informed consent to conduct further diagnostic and research study according to the Declaration of Helsinki as a statement of ethical principles for medical research involving human subjects, including research on identifiable human material and data. All patients received standard medical treatment according to complications and concomitant diseases.

Immediately after collection, the blood was centrifuged using Histopaque 1077 (Sigma, USA), the leucocytes collected were washed and frozen at $-80^{\circ} \mathrm{C}$ until use. The cells were lysed in the extraction buffer with inhibitors of proteases and phosphatases. To determine the amount of phospho-AMPK (phospho-threonine 172) enzyme-linked immunosorbent assay (ELISA) kit ab154468 (Abcam, UK) was used. The protein concentration in the lysate was determined using Novagen (USA) BCA protein assay kit. The measurements were carried out on a microplate reader (Bio-tek Instruments, USA) at a wavelength of $600 \mathrm{~nm}$.

To get the calibration curve for the AMPK determination, a kidney cell culture HEK293T of the human embryonic kidney was used, which is recommended by manufacturer as a positive control. Cells of the HEK293 line derived from the collection of cell cultures of the R. E. Kavetsky Institute of Experimental Pathology, Oncology and Radiobiology of National Academy of Sciences. Cells were cultured in a Dulbecco's Modified Eagle Medium (DMEM) ("Sigma», USA), containing $10 \% \mathrm{em}$ bryonic calf serum («GibcoBRL», UK), $2 \mathrm{mM}$ L-glutamine, $50 \mathrm{IU} / \mathrm{ml}$ penicillin, $50 \mathrm{\mu g} / \mathrm{ml}$ streptomycin ("GibcoBRL», UK), in a humidified atmosphere with $5 \% \mathrm{CO}_{2}$ at $37{ }^{\circ} \mathrm{C}$. The optical density (OD) values of samples obtained (0.005-0.08) are located on the calibration curve region perfectly coinciding with exponential theoretical curves, that indicates no scattering of the data.

Statistical calculations and data presentation were performed using Origin 7.0 software. The results of the study are presented as $\mathrm{M} \pm \mathrm{m}$. To compare the data groups, Student's $t$-test and One-Way ANOVA were used. Values of $\mathrm{P} \leq 0.05$ were considered as significant.

\section{RESULTS AND THEIR DISCUSSION}

\section{Combination of metformin and insulin.}

The patients were divided into groups: the control group consisted of healthy individuals who did not have DM, representative by age $(\mathrm{n}=3)$; patients with T1D on insulin therapy $(n=7)$; patients with type 2 diabetes before the hypoglycemic therapy $(\mathrm{n}=2)$; patients with $\mathrm{T} 2 \mathrm{D}$ receiving metformin at a dose of $1000 \mathrm{mg}$ twice a day as an hypogly- 


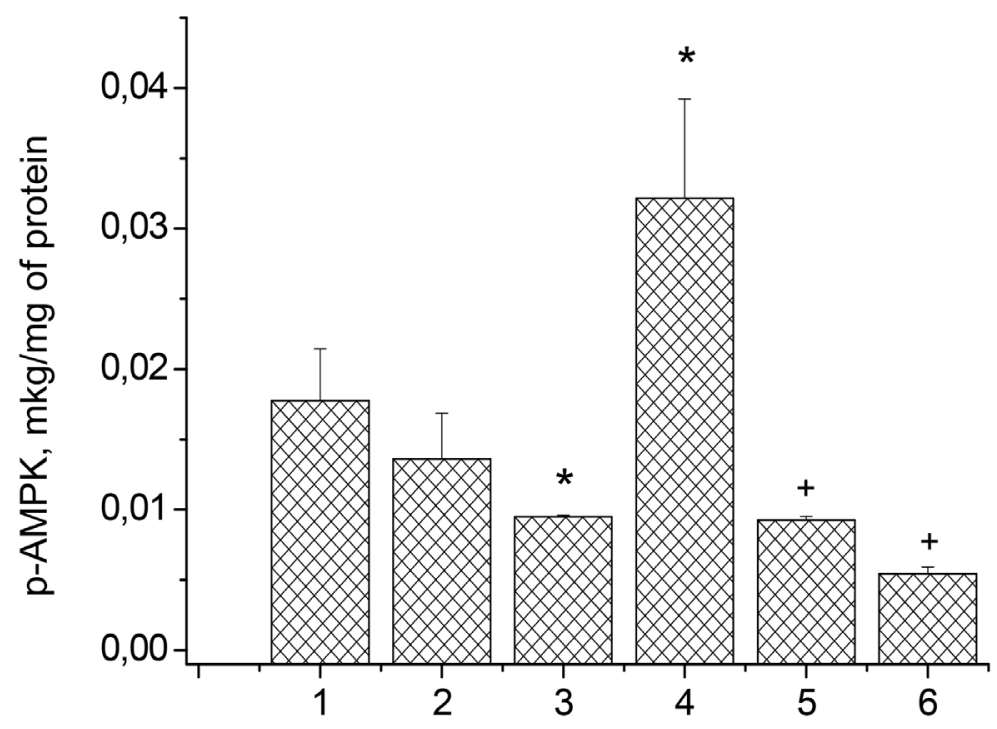

Fig. 1. AMPK activity in leucocytes of diabetic patients before treatment and after taking hypoglycemic drugs.

1 - control ( $\mathrm{n}=3), 2-\mathrm{T} 1 \mathrm{D}(\mathrm{n}=7), 3-$ T2D before treatment $(\mathrm{n}=2), 4-$ metformin $(\mathrm{n}=5)$, 5 - metformin + analogue insulin $(n=2), 6-$ metformin + human insulin $(n=3)$.

$\mathrm{M} \pm \mathrm{m} ;{ }^{*}$ - difference from control - significant, $\mathrm{P}<0,05$

+- difference from effect of metformin - significant, $\mathrm{P}<0,05$.

cemic therapy $(\mathrm{n}=5)$; patients on combined therapy - metformin at a same dose and analogue insulin (glargine) $(n=2)$; patients on combined therapy - metformin and human insulin $(n=3)$; patients on combined therapy metformin + gliclazide $(\mathrm{n}=3)$; patients on gliclazide therapy $(n=3)$; patients with type 2 diabetes who receive the original metformin at a dose of $1000 \mathrm{mg}$ twice a day as monotherapy $(\mathrm{n}=4)$; patients with T2D on combined therapy (original metformin and dapagliflozin) $(\mathrm{n}=3)$; patients with $\mathrm{T} 2 \mathrm{D}$ on combined therapy (generic metformin and dapagliflozin) $(\mathrm{n}=3$ ); patients with T2D who receive dapagliflozin as a monotherapy in a daily dose of $10 \mathrm{mg}(\mathrm{n}=3)$.

Insulin glargine is the first long-acting analogue of human insulin, whose single administration provides 24-hour basal glycemic control.

AMPK activity was determined by the amount of the phosphorylated Thr172 of a-subunit of the protein. Fig. 1 shows that the level of phospho-AMPK in leucocytes of patients with T1D (group 2) does not differ from control, and in patients with T2D before treatment with hypoglycemic drugs (group 3) it is lower than in control samples. Metformin increases more than three-fold the activity of AMPK in blood cells of patients with T2D, which may indicate that the drug affects not only muscles, liver and adipose tissue, but also blood cells. An increase in the activity of protein kinase in blood cells, including monocytes/ macrophages, whose inflammatory process plays an important role in increasing the insulin resistance, may partly explain its attenuation by the action of metformin.

A stimulating effect of metformin on AMPK activity in undifferentiated bone marrow precursor cells was also described [10].

Attention is drawn to the lack of insulin effect on AMPK activity in patients with T1D (group 2), which indicates a certain independence of the insulin-dependent signal pathway PI3K/Akt (phosphatidylinositol-4,5-bisphosphate 3-kinase/v-akt murine thymoma viral oncogene homolog)) from the cascade of AMPK activation LKB1, CAMKK2, and TAK1 (TGFB (transforming growth factor-B)-activated kinase 1). At the same time, both insulin and its analogue, insulin glargine, completely suppressed metformin-stimulated AMPK activity in the leucocytes of patients with T2D (Fig. 1, Groups 5 and 6), reducing it to the level of a group of patients without treatment (group 3).

The latter fact is of particular interest, taking into account that the hyperglycemic effect of metformin is mainly related to suppression 
of the glucose production in the liver by activating the LKB1-AMPK pathway [11].

It is important to note that metformin realizes pleiotropic actions in multiple organs, and exerts protective effects on cardiovascular diseases and pancreatic B-cells failure. Moreover, metformin therapy improves insulin secretion and protects against palmitic acid-induced pancreatic B-cell apoptosis, therefore supporting the advantageous effects of metformin on pancreatic B-cells. Metformin also exerts direct effects on B-cell function such as insulin release, transcriptional regulation in pancreatic islets, and islet cell viability, in dependence on glucose concentration [12].

Therefore, insulin inhibition of AMPK activity is perhaps a feedback mechanism regulating the synthesis and secretion of the hormone itself. It should be noted that insulin suppresses AMPK activity not only in leucocytes, but also in the liver, muscles, and possibly in other tissues and organs [13].

As for the mechanism of such inhibition, so far little is known. There is evidence that insulin can inhibit adrenergic agonist-stimulated AMPK [14]. Recent studies also suggest that insulin downregulates AMPK activity via Ser485/491 phosphorylation of the AMPK a-subunit [15].

Taking into account the obtained data, it is possible that the inhibition of AMPK and, accordingly, the effect of metformin, by insulin in their combined application, can explain complications in the cardiovascular and excretory systems [7-9]. On the other hand, many disadvantages of insulin treatment in type 2 diabetes seem to be minimized by concomitant treatment with metformin. Metformin and insulin versus insulin alone seems to cause favorable reductions in weight, HbA1c, and insulin dose [16].

\section{Combination of metformin and sulfonylureas.}

Over the past 50 years, sulfonylureas have taken a leading position in the treatment of T2D. The use of gliclazide MR has made it possible to safely achieve the target level of $\mathrm{HbA1c}$ in most patients, regardless of such factors as the age of patients, prescription of the disease, previous hypoglycemic therapy, baseline
HbA1c, body mass index. The obtained results allowed to prove the clinical and prognostic efficacy of gliclazide MR [17]. The main hypoglycemic effect of these drugs is associated with effect on B-cells and increased secretion of insulin, but each of the drugs of this group has its own characteristics [18].

Since the leading causes of death among patients with T2D are diseases of the cardiovascular system, the greatest importance is the influence of the hypoglycemic agents on the risk of development and progression of cardiovascular pathology.

The stimulation of AMPK activity in the blood cells of patients receiving gliclazide MR was somewhat unexpected (Fig. 2), and the effect of the drug was significantly higher than that of metformin.

In B-cells, ATP-sensitive potassium channels (KATP) associate glucose stimulation with membrane depolarization. It was shown that AMPK affects the activity of KATP in B-cells, enhancing their migration to the cell membrane by remodeling the cytoskeleton [19]. The effect of leptin, which inhibits the secretion of insulin, is mediated by AMPK and also associated with increased movement of KATP to the cell membrane [20].

Decrease in glucose production by hepatocytes occurs due to the activation of the signal chain: AMPK $\rightarrow$ malonyl-CoA (coenzyme A) $\rightarrow$ CPT-1 (carnitine palmitoyltransferase I) $\rightarrow$ LCFA-CoA (long chain fatty acyl coenzyme A) $\rightarrow$ PKC- $\delta$ (protein kinase C $\delta$ ), leading to activation of KATP channels [21]. Thus, AMPK activation counteracts the effect of gliclazide in B-cells. A possible explanation for this fact is the compensatory activity of B-cells in restoring the function of potassium channels closed by sulfonylureas, by increasing their quantity on the cell membrane. Interest is also caused by the fact that AMPK activity decreases in the presence of both hypoglycemic agents. Perhaps this is due to the competitive interaction of the general signaling mechanisms activating this protein kinase.

The assumption that gliclazide can stimulate the AMPK activity in other tissues and organs can explain the increase in insulin sensitivity of the cells of target organs - liver, adipose and muscle tissue. 


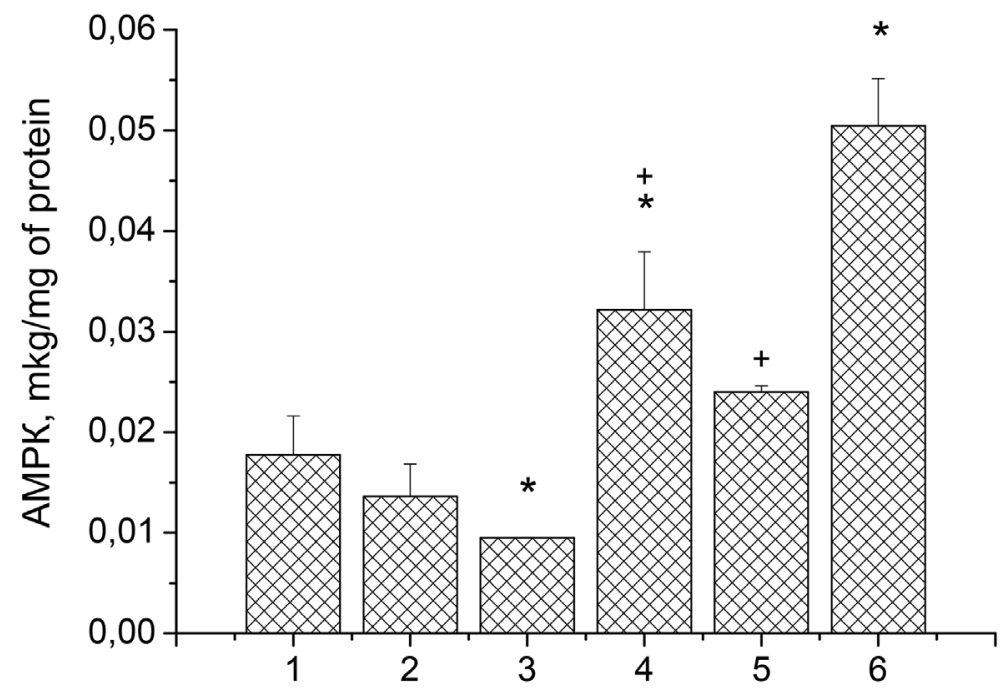

Fig. 2. AMPK activity in leucocytes of patients with diabetes mellitus before and after treatment with hypoglycemic agents.

$1-$ control $(\mathrm{n}=3), 2-\mathrm{T} 1 \mathrm{D}(\mathrm{n}=7), 3-$ T2D before treatment $(\mathrm{n}=2)$,

4 - metformin $(n=5), 5-$ metformin + gliclazide $(n=3), 6-$ gliclazide $(n=3)$. $\mathrm{M} \pm \mathrm{m} ; *$ - differences from the control are significant, $\mathrm{P}<0,05$;

+ - differences from the action of gliclazide (Diabeton MR) are significant, $\mathrm{P}<0,05$.

The mechanism of AMRK activation by gliclazide has not been studied sufficiently. It is known that the action of sulfonylurea in B-cells develops in two ways: through KATR and through exchange protein activated by cAMP 2A (Epac2A), which is also a target for sulfonylurea. As a result, the overall effect of the drug on insulin secretion is achieved [22]. Epac2A through activation of LKB1 stimulates phosphorylation and activation of AMPK [23].

\section{Combination of metformin and dapagliflozin.}

AMPK controls the energy balance of the cell. With T2D and obesity, its activity decreases, and the activity of protein kinases mTORC1/p70S6K (mammalian target of rapamycin complex 1/ribosomal protein S6 kinase beta-1) increases, leading to phosphorylation of insulin receptor substrate- 1 and insulin resistance [24]. The effect of hypoglycemic drugs, such as metformin, is associated with the activation of AMPK, and dapagliflozin - with the inhibition of the sodium/glucose cotransporter 2 (SGLT2), responsible for the reabsorption of glucose in the proximal tubules of the kidney [25].

According to the results obtained, the original metformin and generic metformin increase the activity of AMPK in blood cells more than
6 and 3 times, respectively (Fig. 3, 4 and 6), which may indicate the advantages of the original drug.

The most interesting data were obtained using dapagliflozin — a powerful (inhibition constant of $0.55 \mathrm{nM}$ ), selective, reversible inhibitor of the SGLT2. Dapagliflozin itself increases the activity of AMPK (Fig. 3, 8), and moreover has an additive effect under the action of generic metformin (7), which was not observed with respect to the original metformin drug (Fig. 3, 5). Probably, the values of $0.06-0.08 \mathrm{mkg} / \mathrm{mg}$ of phosphorylated protein are saturating, limiting concentration and the limiting level of AMPK activation in blood mononuclear cells.

It is known that the effect of metformin is mainly related to the suppression of the formation of glucose in the liver by activating the LKB-AMPK pathway [11]. Therefore, data on the increase in enzyme activity in blood cells are of certain interest. On the one hand, this indicates a possible universal action of biguanides on all tissues of the body, including macrophages, the inflammatory process in which, due to obesity, plays an important role in enhancing insulin resistance. On the other hand, it allows to quickly and easily evaluate the therapeutic effect of the drugs used, which is important for prognostic purposes. 
Since dapagliflozin is used relatively recently, the molecular mechanisms of its action on the tissues of the body, besides the kidneys, have not been studied enough. In the epithelium of the kidneys, it inhibits the expression of the proapoptotic protein Bax, thereby inhibiting apoptosis, and enhances the expression of the hypoxia inducible factor (HIF1) [26]. In vitro, dapagliflozin dose-dependently increased the expression of HIF1, AMPK and ERK (extracellular signal-regulated kinase) and increased the survival of HK2 (human kidney-2) cells - immortalized hypoxic epithelial cells of the adult kidney tubules [26]. An increase in the expression of HIF1, AMPK, ATP consumption and suppression of apoptosis in epithelial cells may indicate additional positive effects of dapagliflozin in cardiovascular diseases [27].

The question arises as to how the activity of AMPK in blood cells corresponds to its activity in metabolic tissues, which are actually affected by hypoglycemic drugs. To clarify this issue, additional research is needed. If such a correspondence will be established, the level of AMRK in leukocytes, due to their availability for analysis, may be a promising diagnostic parameter. Also the limitations of this study are small samples, as a result of which it is possible to speak more about trends. This is due to the complexity of patient's recruitment on monotherapy and with some combinations of glucose-lowering drugs.

Thus, the level of activated AMPK is quite a sensitive indicator that clearly responds to the hypoglycemic drugs used. Since leukocytes are the most accessible biomaterial, determining the amount of AMPK in the blood cells can provide additional information about the efficacy of drugs, synergism or antagonism with their combined use, as well as about the degree of improvement of insulin signaling and the weakening of insulin resistance.

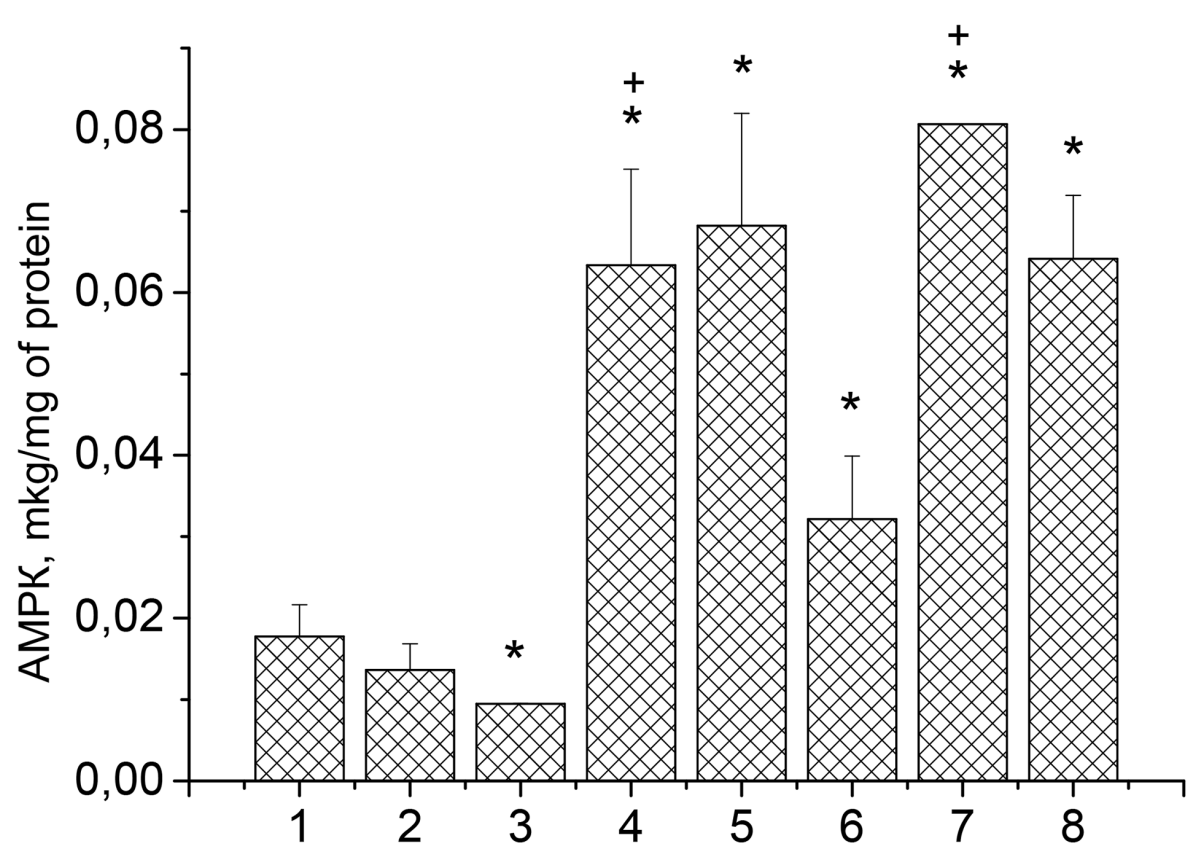

Fig. 3. AMPK activity in patients with diabetes mellitus before and after treatment with hypoglycemic agents.

The control group (1) comprised individuals who did not have diabetes mellitus, representative by age $(n=3), 2$ - patients with type 1 diabetes on insulin therapy $(n=7)$,

3 - patients with diabetes before the start of hypoglycemic therapy $(n=2)$,

4 - patients with type 2 diabetes who receive the original metformin at a dose of $1000 \mathrm{mg}$

twice a day as monotherapy $(\mathrm{n}=4), 5$ - patients with T2D on combination therapy (original metformin and dapagliflozin) $(\mathrm{n}=3), 6$ - patients with T2D who receive generic metformin $1000 \mathrm{mg}$ twice a day as a hypoglycemic therapy $(n=5), 7$ - patients with T2D on combination therapy (generic metformin and dapagliflozin) $(\mathrm{n}=3), 8$ - patients with T2D who receive dapagliflozin as a monotherapy in a daily dose of $10 \mathrm{mg}(\mathrm{n}=3)$.

$\mathrm{M} \pm \mathrm{m} ; *$ - differences from the control (1) are significant, $\mathrm{P}<0,05$;

+ - differences from the action of generic metformin (6) are significant, $\mathrm{P}<0.05$. 


\section{CONCLUSIONS}

1. Metformin increases the activity of AMPK in blood cells of patients with T2D more than 3-fold, compared with T2D patients before treatment that may suggest a direct effect of the drug on monocyte/macrophage system.

2. Insulin and its analogue completely suppress metformin-stimulated AMPK activity in leucocytes of patients with T2D and, consequently, insulin can interfere with the therapeutic effects of metformin.

3. Gliclazide MR increases the activity of AMPK in blood mononuclear cells.

4. The decrease in AMPK activity in leucocytes in the presence of metformin and gliclazide
MR may be due to their competition with respect to the general signaling mechanisms involved in the activation of protein kinase.

5. Dapagliflozin increases the activity of AMPK in mononuclear cells and enhances the effect of metformin on the activity of AMPK in blood cells.

6. The activity of AMPK in blood cells may serve as one of the indicators of the effectiveness of the hypoglycemic drugs action.

7. Increased AMPK activity in blood cells suggests a possible universal action of biguanides, dapagliflozin and sulfonylureas on all tissues of the body.

\section{ЛITEPATУРA \\ (REFERENCES)}

1. Ruderman NB, Carling D, Prentki M, Cacicedo JM. $J$ Clin Invest 2013; 123(7): 2764-2772. doi: 10.1172/JCI67227.

2. Xiao B, Sanders MJ, Underwood E, et al. Nature 2011; 472(7342): 230-233. doi: 10.1038/nature09932.

3. Racioppi L, Means AR. J Biol Chem 2012; 287(38): 31658-31665. doi: 10.1074/jbc.R112.356485.

4. Jeong KJ, Kim GW, Chung SH. J Ginseng Res 2014;38: 83-88. doi: 10.1016/j.jgr.2013.11.014.

5. An H, He L. J Endocrinol 2016; 228(3): R97-R106. doi: 10.1530/JOE-15-0447.

6. Diabetes Care 2018; 41(1): S1-S2. doi.org/10.2337/dc18Sint01.

7. Hung AM, Roumie CL, Greevy RA, et al. Clin J Am Soc Nephrol 2016; 11(12): 2177-2185. doi: 10.7326/00034819-157-9-201211060-00003.

8. Roumie CL, Greevy RA, Grijalva CG, et al. JAMA 2014; 311(22): 2288-2296. doi: 10.1001/jama.2014.4312.

9. Roumie CL, Min JY, D'Agostino McGowan L, et al. J Am Heart Assoc 2017; 6(4): e005379. doi: 10.1161/ JAHA.116.005379.

10. Molinuevo MS, Schurman L, McCarthy AD, et al. J Bone Miner Res 2010;25(2): 211-221. doi: 10.1359/jbmr.090732.

11. Meng S, Cao J, He Q, et al. J Biol Chem 2015; 290 : 3793-3802. doi: 10.1074/jbc.M114.604421.

12. Yang X, Xu Z, Zhang C, et al. Biochim Biophys Acta 2017; 1863(8): 1984-1990. doi: 10.1016/j.bbadis.2016.09.019.

13. Valentine RJ, Coughlan KA, Ruderman NB, Saha AK. Arch Biochem Biophys 2014; 562: 62-69. doi: 10.1016/j. abb.2014.08.013.

14. Omar B, Zmuda-Trzebiatowska E, Manganiello V, et al. Cell Signal 2009; 21(5): 760-766. doi: 10.1016/j.cellsig.2009.01.015.
15. Kido K, Yokokawa T, Ato S, et al. Am J Physiol Regul Integr Comp Physiol 2017; 313(2): R110-R119. doi: 10.1152/ ajpregu.00063.2017.

16. Hemmingsen B, Schroll JB, Wetterslev J, et al. CMAJ Open 2014; 2: E162-E175. doi: 10.9778/cmajo.20130073.

17. ADVANCE Collaborative Group, Patel A, MacMahon S, et al. $N$ Engl J Med 2008; 358: 2560-2572. doi: 10.1056/ NEJMoa0802987.

18. Hirst JA, Farmer AJ, Dyar A, et al. Diabetologia 2013; 56: 973-984. doi: 10.1007/s00125-013-2856-6.

19. Han YE, Lim A, Park SH, et al. Exp Mol Med 2015; 47: e190. doi: 10.1038/emm.2015.72.

20. Wu Y, Shyng SL, Chen PC. J Biol Chem 2015; 290(50): 29676-29690. doi: 10.1074/jbc.M115.670877.

21. Abraham MA, Yue JT, LaPierre MP, et al. Mol Metab 2013; 3(2): 202-208. doi: 10.1016/j.molmet.2013.11.007.

22. Seino S. Diabetologia 2012; 55: 2096-2108. doi: 10.1007/ s00125-012-2562-9.

23. Homolya L, Fu D, Sengupta P, et al. PLoS One 2014; 9(3): e91921. doi: 10.1371/journal.pone.0091921.

24. Saha AK, Xu XJ, Balon TW, et al. Cell Cycle 2011; 10(20): 3447-3451. doi: 10.4161/cc.10.20.17886.

25. Filippatos TD, Liberopoulos EN, Elisaf MS. Ther Adv Endocrinol Metab 2015; 6(1): 29-41. doi: 10.1177/ 2042018814558243.

26. Chang YK, Choi H, Jeong JY, et al. PLoS One 2016; 11(7): e0158810. doi: 10.1371/journal.pone.0158810.

27. Zinman B, Wanner C, Lachin JM, et al. New Engl J Med 2015; 373(22): 2117-2128. doi: 10.1056/NEJMoa1504720. 


\title{
ВПЛИВ КОМБІНОВАНОГО ЛІКУВАННЯ ІНСУЛІНОМ ТА ІНШИМИ ЦУКРОЗНИЖУВАЛЬНИМИ ПРЕПАРАТАМИ НА АКТИВНІСТЬ 5'-АМФ-АКТИВОВАНОÏ ПРОТЕЇНКІНАЗИ У ЛЕЙКОЦИТАХ ХВОРИХ НА ЦУКРОВИЙ ДІАБЕТ 2 ТИПУ
}

Пушкарьов В. В., Соколова Л. К., Пушкарьов В. М., Бельчина Ю. Б., Вацеба Т. С., Тронько М. Д.

ДУ "Інститут ендокринологї̈ та обліну речовин іл. В. П. Колісаренка НАМН Украӥни», м Київ, Україна

pushkarev.vm@gmail.com

До складу лейкоцитів входять моноцити/макрофаги і лімфоцити - клітини, запалення і інфільтрація яких, є важливою подією в патогенезі діабету і пов'язаних з ним ускладнень.

Методом імуноферментного аналізу визначали активність 5'-аденозинмонофосфат-активованої протеїнкінази (AMPК), що контролюе енергетичний баланс клітини, в клітинах крові при комбінованому лікуванні хворих на діабет 2 типу (ЦД2) інсуліном, метформіном, гліклазидом MR i дапагліфлозіном. Показано, що препарати метформіну збільшують активність АМРК в клітинах крові паціентів з ЦД2 більш ніж в 3-6 разів у порівнянні з хворими до лікування. Інсулін і його аналог повністю пригнічують активність АМРК, індуковану метформіном в лейкоцитах пацієнтів з ЦД2, що може свідчити про зниження терапевтичного ефекту метформіну. Гліклазид MR збільшуе активність AMPК в мононуклеарах крові. За присутності метформіну і гліклазиду рівень фосфорилювання АМРК знижуеться. Механізм активації AMPK гліклазидом MR, ймовірно, пов'язаний з ефектом останнього на Ерас2А. Дапагліфлозін підвищуе активність АMPK і посилюе ефект метформіну в лейкоцитах хворих ЦД2. Активність АMPK в клітинах крові може слугувати одним з показників ефективності дії гіпоглікемічних препаратів.

Обговорюються механізми взаємодії препаратів та наслідки їх антагонізму.

Ключові слова: АМРК, лейкоцити, діабет 2 типу, метформін, інсулін, гліклазид MR, дапагліфлозін.

\section{ВЛИЯНИЕ КОМБИНИРОВАННОГО ЛЕЧЕНИЯ ИНСУЛИНОМ И ДРУГИМИ САХАРОСНИЖАЮЩИМИ ПРЕПАРАТАМИ НА АКТИВНОСТЬ АМФ-АКТИВИРУЕМОЙ ПРОТЕИНКИНАЗЫ В ЛЕЙКОЦИТАХ БОЛЬНЫХ САХАРНЫМ ДИАБЕТОМ 2 ТИПА}

\author{
Пушкарев В. В, Соколова Л. К., Пушкарев В. М., \\ Бельчина Ю. Б., Вацеба Т. С., Тронько Н. Д. \\ ГУ "Институт эндокринологии и облена веществ им. В. П. Колисаренко НАМН Украинь», \\ г. Киев, Украина \\ pushkarev.vm@gmail.com
}

В состав лейкоцитов входят моноциты/макрофраги и лимфоциты - клетки, воспаление и инфильтрация которых, является важным событием в патогенезе диабета и связанных с ним осложнений. Методом иммуноферментного анализа определяли в лейкоцитах уровень фоссрорилирования остатка треонина 172 (активацию) 5'аденозинмонофосфат-активируемой протеинкиназы (АМРК), контролирующей энергетический баланс клетки, при комбинированном лечении больных диабетом 2 типа (СД2) инсулином, метформином, гликлазидом MR и дапаглифлозином. Показано, что препараты метформина увеличивают активность AMPK в клетках крови пациентов с СД2 более чем в 3-6 раз по сравнению с больными до лечения. Инсулин и его аналог полностью подавляют активность АМРК, индуцированную метформином в лейкоцитах пациентов с СД2, что может свидетельствовать о снижении терапевтического әффекта метформина. Гликлазид MR увеличивает активность AMPK в мононуклеаpax крови. В присутствии метформина и гликлазида уровень фосфорилирования АМРК снижается. Механизм активации AMPK гликлазидом MR, вероятно, связан с әффектом последнего на Ерас $2 \mathrm{~A}$. Дапаглифлозин повышает активность AMPК и усиливает эффект метформина в лейкоцитах больных СД2. Активность AMPK в клетках крови может служить одним из показателей әффективности действия гипогликемических препаратов.

Обсуждаются механизмы взаимодействия препаратов и последствия их антагонизма.

Ключевые слова: АМРК, лейкоциты, диабет 2 типа, метформин, инсулин, гликлазид МR, дапаглифрлозин. 


\section{EFFECT OF COMBINED TREATMENT \\ WITH INSULIN AND OTHER HYPOGLYCEMIC DRUGS \\ ON 5'AMP-ACTIVATED PROTEIN KINASE ACTIVITY IN LEUCOCYTES OF PATIENTS WITH DIABETES MELLITUS}

V. V. Pushkarev, L. K. Sokolova, V. M. Pushkarev,

Y. B. Belchina, T. S. Vatseba, M. D. Tronko

SI «V. P. Komisarenko Institute of Endocrinology and Metabolism of NAMS of Ukraine», Kiev, Ukraine

pushkarev.vm@gmail.com

The composition of leukocytes includes monocytes/macrophages and lymphocytes - cells, inflammation and infiltration of which is an important event in the pathogenesis of diabetes and related complications.

The enzyme immunoassay method determined in leukocytes the level of threonine 172 phosphorylation (activation) of 5'adenosine monophosphate-activated protein kinase (AMPK), which controls the cell energy balance, in the combined treatment of patients with with insulin, metformin, gliklazidy MR and g, and the rats of heart and glyclaside MR and chromploidine, and ga;

The level of threonine 172 phosphorylation (activation) of 5'-adenosine monophosphate-activated protein kinase (AMPK), controlling the energy balance of the cell, at combination treatment of patients with type 2 diabetes (T2D) with insulin, metformin, gliclazide and dapagliflozin was determined in blood cells by enzyme immunoassay. It has been shown that metformin drugs increase the activity of AMPK in the blood cells of patients with T2D more than 3-6 times compared with patients before treatment. Insulin and its analogue completely suppress AMPK activity, induced by metformin in the leucocytes of patients with T2D, which may indicate a decrease in the therapeutic effect of metformin. Gliclazide MR increases the activity of AMPK in blood mononuclear cells. In the presence of both metformin and gliclazide, the level of AMPK phosphorylation is reduced. The mechanism of activation of AMPK by gliclazide probably related to the effect of the latter on Epac2A. Dapagliflozin increases the activity of AMPK and enhances the effect of metformin in the leucocytes of patients with T2D. AMPK activity in blood cells can serve as one of the indicators of the effectiveness of the hypoglycemic drugs action.

The mechanisms of drug interaction and the consequences of their antagonism are discussed.

Key words: AMRK, leukocytes, type 2 diabetes, metformin, insulin, gliclazide MR, dapagliflozin. 